\title{
Metasomatic wherlite dyke stockworks within anisotropic mantle lithosphere
}

\author{
David B. Snyder ${ }^{1}$ and Grant Lockhart ${ }^{2}$ \\ ${ }^{1}$ Geological Survey of Canada, Natural Resources Canada, Ottawa, Ontario, Canada \\ ${ }^{2}$ Indicator Minerals Inc., Vancouver, BC Canada
}

Individual kimberlite pipes have long been recognised geochemically to root at depths of several kilometres into vertical sheets or dykes composed of kimberlite clan rocks that represent $<1 \%$ partial melts of carbonated lherzolite within sublithospheric mantle (e.g. Canil \& Scarfe 1990). At greater depths, these kimberlite dykes were hypothesized to transition into older carbonated, hydrated or metasomatised peridotite rock within the lithospheric mantle (Malkovits et al. 2007), perhaps forming dyke swarms or stockworks above pockets of low-percentage mantle melt (Sleep 2003; Grégoire et al. 2005). Combined analysis of very precise isotopic age dating and azimuthal anisotropy observed in teleseismic waves supports the interpretation that one dyke feeds several kimberlite pipes and that these dykes become more numerous, to from swarms or stockworks, at depths of 100-300 km (Fig. 1) (Snyder \& Lockhart 2003). Geochemical and petrological observations indicate that a substantial percentage of these dykes are more accurately characterized as fossil metasomatised fluid conduits rather than either mantle rock or kimberlite (e.g. Malkovets et al. 2007). Here we review the evidence derived from seismic anisotropy for extensive, aligned dyke swarms in the mantle lithosphere beneath the Lac de Gras kimberlite field in NW Canada and the more general significance of such structures for diamond exploration.

Combined high-precision isotope dating of coeval, individual Lac de Gras kimberlite pipe eruptions and remnant magnetization correlations provide consistent estimates of inferred dyke orientation at the surface; trend estimates that are distinct from all known dyke and fracture swarm trends (Snyder \& Lockhart 2003). The depth extent of kimberlitic dyke swarms beneath the Lac de Gras field is indicated by two independent seismic analytical techniques. The volume occupied by the dykes can be estimated from delay times observed between orthogonally polarized SKS-seismic wave components that traverse the core before becoming polarized and emerging at the recording station (Fig. 2) (Snyder \& Bruneton 2007). The orientation of the dykes is determined by this same technique, but also by the azimuthal dependence of wave conversions at major discontinuities in the mantle, using the so-called receiver function method (Fig. 3) (e.g. Bostock 1989). Both methods reveal a NE-SW $\left(050^{\circ}\right)$ orientation for the deep dykes that coincides with a similarly aligned inferred fabric within the host mantle peridotite. This latter fabric could be either fractures or aligned mineral crystals. Aligned mineral crystals or fractures could have a direct cause and effect relationship to the kimberlite dykes (Gregoire et al. 2005) or result from their mutual creation within a similar continental stress field. These anisotropically fast polarization directions agree within a few degrees with surface trends of inferred coeval kimberlite eruptions; the kimberlite dyke trends and the mantle peridotite fabric trends are both strain features that are consistent with the continental stress field hypothesized for the North American plate from the Eocene to Present (Snyder \& Lockhart 2003).

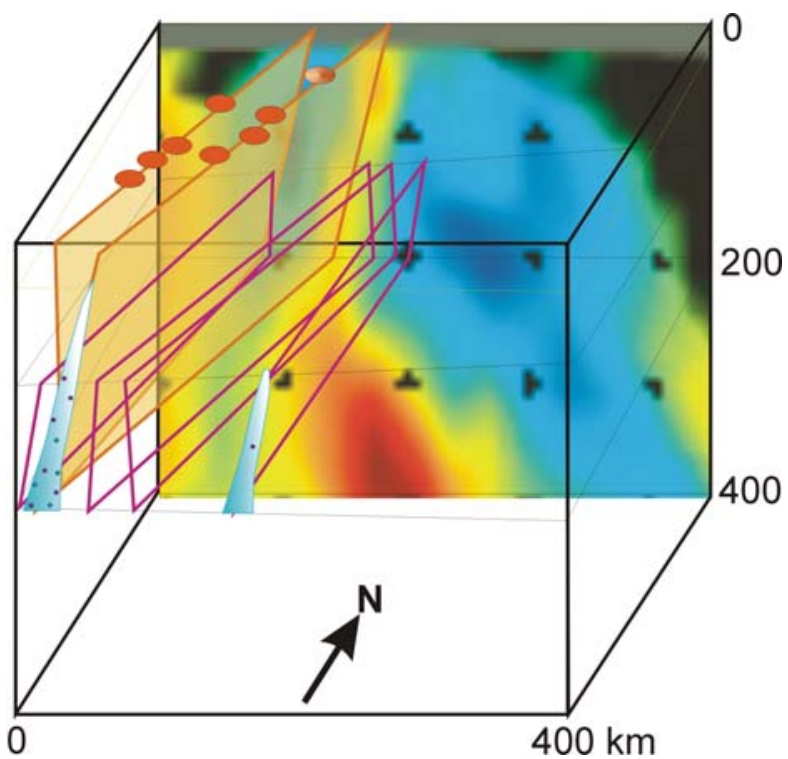

Figure 1. Cube showing hypothetical structures in the mantle beneath the Lac de Gras kimberlite field in the central Slave craton of NW Canada. Cube is $400 \mathrm{~km}$ in each dimension. Back face of the cube is a P-wave travel-time study showing seismic wave speed anomalies from $+1 \%$ (blue) to $-1 \%$ (red) (K. Straub \& S. Rondenay, unpub. data). The slower speeds are shown to coincide with near-vertical dykes composed of metasomatized peridotite and kimberlite (pale blue shapes in front face) within the lithosphere (depths $<200 \mathrm{~km}$ ); these dykes beak into kimberlite pipes (orange ovals) within a few kilometres of the surface. Not all dykes reach the surface. A region of even 
slower P-wave speeds lies within the asthenosphere beneath the kimberlite field at $400 \mathrm{~km}$ depth.

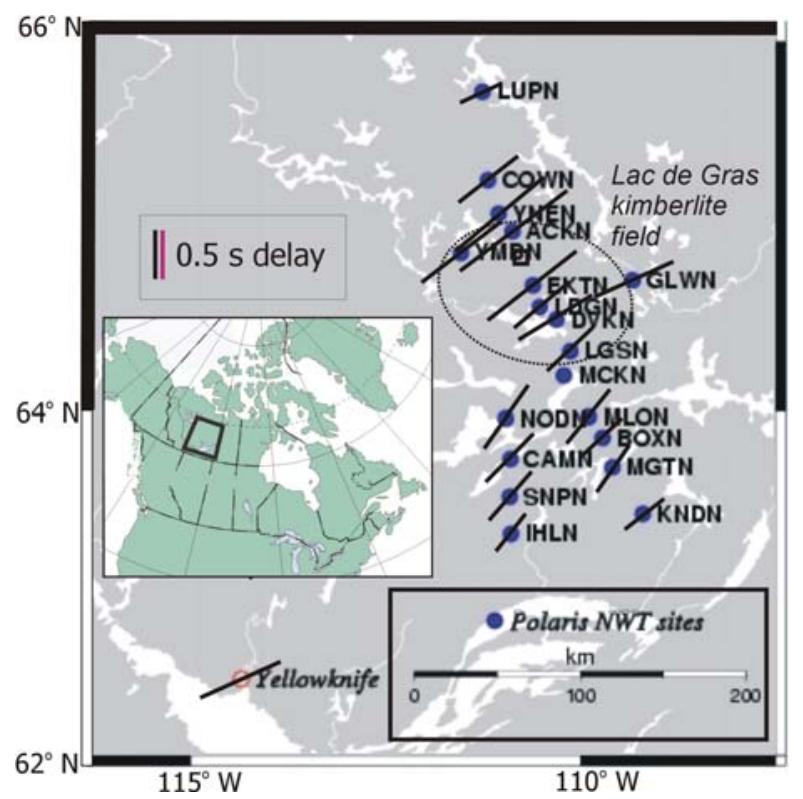

Figure 2. Location of the POLARIS Slave (NW Territories) array. Black line segments indicate fast polarization and delay time of SKS/SKKS waves for anisotropic layers as modelled using seismic waves recorded at that station. The strength of the delays (length of the line segments) within the Lac de Gras kimberlite field is about twice that observed at stations outside the field implying an additional source of anisotropy in the underlying mantle.

The volume and bulk seismic properties of the dyke swarms at depth must be estimated from the delay time of SKS polarizations and by assuming the velocities at which S-waves propagate through normal mantle, metasomatised mantle and kimberlites. Delays of as much as 0.2 seconds observed within the Lac de Gras field imply as much as $10-30 \%$ of the mantle between 110 and $190 \mathrm{~km}$ depths has lower velocities than does the "country rock" of highly refractory harzburgite (Fig. 1). This harzburgite may contain neither garnet nor diamond because it was never effected by metasomatism or kimberlite emplacement (Malkovits et al. 2007). This volume percentage estimate decreases inversely as the contrast in seismic wave propagation speed increases between primitive peridotite and metasomatised rock increases. Kimberlites are estimated to contain up to $10 \% \mathrm{H}_{2} \mathrm{O}$ and $\mathrm{CO}_{2}$ (Sparks et al. 2006) and laboratory measurements on kimberlite samples produce densities and wave-speeds of 2.3 $\mathrm{g} / \mathrm{cm}^{3}$ and $2.5 \mathrm{~km} / \mathrm{s}$, consistent with these volatile contents. Forward modelling of the receiver function responses predicts that most of the dykes are truncated at their shallow end by a planar surface that strikes at $200^{\circ}$ and dips at $20^{\circ}$ to the west. This capping surface could be a change in lithology (e.g. eclogite-rich layer) or a regional structure.

Other sources of seismic anisotropy such as crystal alignment within mantle layers that is traditionally attributed to deformation associated with plate motion may similarly reduce the estimates of kimberlite dyke volume density, but not below about $5 \%$ given that the greater anisotropy is observed only within the Lac de Gras field. The Lac de Gras field has nearly 350 recognized kimberlite pipes, but only three NE-SW dykes are currently recognized within the field and these dykes do not represent $5-10 \%$ of the rock exposed at the surface. Either only a small percentage of kimberlite eruptions reach the surface or else metasomatic zones surrounding kimberlite conduits provide equivalent velocity contrasts and occupy much larger volumes in the mantle than do the kimberlites themselves.
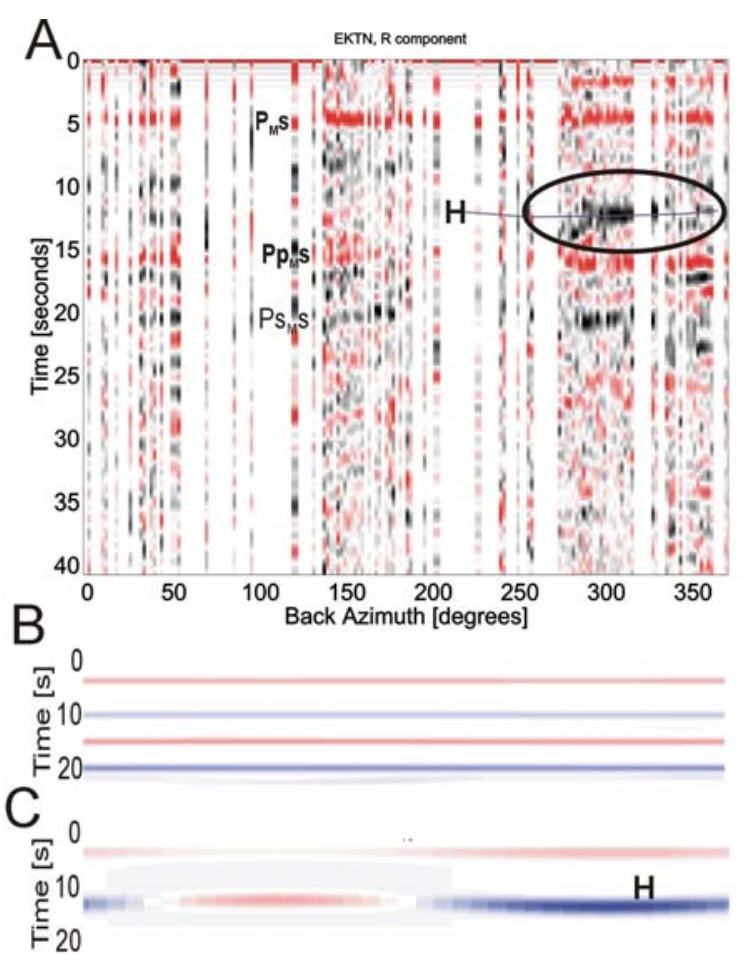

Figure 3. (A) Radial seismic response 0 to $40 \mathrm{~s}$ after the direct P-wave arrives, plotted as a function of back azimuth to the source earthquake from station EKTN at the Ekati Diamond Mine. (B) Synthetic response from a model of upper mantle with two layers of anisotropy (Snyder \& Bruneton 2007), including reverberations of the Moho (PmS). (C) Synthetic radial response from a dyke model with $4 \%$ anisotropy and dykes oriented at $045^{\circ}$, without reverberations. $\mathrm{H}$ and oval mark the signature of the dyke swarm as modelled here.

Dense stock works of metasomatized kimberlitic mantle may only occur, or only be recognized, beneath populous kimberlite fields such as Lac de Gras. Within some cratons or continental shields such stock works could exist, but have few dykes or pipes that reached the present surface. The metasomatized peridotite volumes beneath Lac de Gras of $10-30 \%$ should, however, produce sufficient variation is $\mathrm{P}$ - or S-wave velocities to cause anomalies on regional- or continental-scale velocity models that use relatively dense networks of seismic stations, such as those recently available in northern Canada. 
Global S-wave velocity models of North America that use low resolution tomographic methods (e.g., Bedle \& van der Lee 2007) contain lower velocities beneath the Lac de Gras field than elsewhere within the Slave craton at a depth of $150 \mathrm{~km}$. Regional-scale, P-wave tomography models also reveals mantle volumes beneath the Lac de Gras field in which P-waves travel more slowly (Fig. 1). Both methods may thus be sufficiently sensitive to detect the presence of deep dyke swarms, or a large volume of carbonate metasomatism, such as is described here. If true, this could provide a valuable exploration tool with which to select areas with enhanced diamond and kimberlite potential. Follow-up, regional seismic anisotropy studies could then identify preferred trends of dykes or aligned pipes.

References

Bedle, H., van der Lee, S. 2007. Upper mantle Svelocity variance beneath North America. Eos Trans. AGU, 88(52), Fall Meeting Supplement, abstract S41B-562.

Bostock, M.G. 1998. Seismic stratigraphy and evolution of the Slave province, Journal of Geophysical Research, 103, 21183-21200.

Canil, D., Scharfe, C. M. 1990. Phase relations in peridotite $+\mathrm{CO}_{2}$ systems to $12 \mathrm{GPa}$ : implication for the origin of kimberlite and carbonate stability in the Earth's mantle. Journal of Geophysical Research, 95, 15805-15816.

Grégoire, M., Rabinowicz, M., Janse, A. J. A. 2005. Mantle mush compaction: a key to understand the mechanisms of concentration of kimberlite melts and intitiation of swarms of kimberlite dykes. Journal of Petrology, 47, 631-646.

Malkovets, V. G., Griffin, W. L., O’Reilly, S. Y., Wood, B. J., 2007. Diamond, subcalcic garnet, and mantle metasomatism: kimberlite sampling patterns define the link. Geology, 35, 339-342.

Sleep, N. H. 2003. Geodynamic implications of xenolith geotherms. Geochemistry Geophysics Geosystems, 4, doi:10.1029/2003GC000511.

Snyder, D. B., Bruneton, M., 2007. Seismic Anisotropy of the Slave craton, NW Canada, from joint interpretation of SKS and Rayleigh waves. Geophysical Journal International, 169, 170188.

Snyder, D.B., Lockhart, G.D., 2005. Kimberlite trends in NW Canada, J. Geol. Soc. London, 162, 737740.

Sparks, R. S. J., Baker, L., Brown, R.J., Field, M., Schumacker, J., Stripp, G., Walters, A. 2006. Dynamical constraints on kimberlite volcanism. Journal of volcanology and Geothermal research, 155, 18-48. 